\title{
Formulation of Biochar-Compost and Phosphate Solubilizing Fungi from Oil Palm Empty Fruit Bunch to Improve Growth of Maize in an Ultisol of Central Kalimantan
}

\author{
Gusti Irya Ichriani ${ }^{1}{ }^{2}$, Syehfani $^{3}$, Yulia Nuraini ${ }^{3}$, Eko Handayanto ${ }^{4 *}$ \\ 1 Postgraduate Programme, Faculty of Agriculture, Brawijaya University, Jl. Veteran, Malang 65145, Indonesia \\ 2 Faculty of Agriculture, University of Palangka Raya, Jl. Yos Sudarso, Kota Palangka Raya 74874, Central \\ Kalimantan, Indonesia \\ 3 Department of Soil Science, Faculty of Agriculture, Brawijaya University, Jl. Veteran, Malang 65145, Indonesia \\ 4 Research Centre for Management of Degraded and Mining Lands, Brawijaya University, Jl. Veteran, Malang \\ 65145 , Indonesia \\ * Corresponding author's e-mail: handayanto@ub.ac.id
}

\begin{abstract}
The efficiency of phosphorus uptake by plants in an Ultisol soil is very low because most of the soil phosphorus is precipitated by $\mathrm{Al}$ and $\mathrm{Fe}$. Oil palm empty fruit bunches can be used as basic materials of biochar and compost, and as sources of isolates of phosphate solubilizing fungi. This study was aimed at elucidating the effect of application of phosphate-solubilizing fungi with biochar and the compost produced from oil palm empty fruit bunches on the growth and yield of maize an Ultisol of Central Kalimantan. This study consisted of two experiments. The first experiment was inoculation of four isolates of phosphate solubilizing fungi isolated from of oil palm empty fruit bunches, i.e. Acremonium (TB1), Aspergillus (TM7), Hymenella (TM1) and Neosartorya (TM8) to 'biocom' media (mixture of biochar and compost generated from oil palm empty fruit bunches) to obtain phosphate-solubilizing fungi that can adapt to the media. In the second experiment, the best results in the first experiment were applied to an Ultisol soil planted with maize. The results showed that the isolates that were best adapted to biocom media were Aspergillus-TB7 with $60: 40$ proportion (60\% biochar $+40 \%$ compost) and Neosartorya-TM8 with $70: 30$ proportions $(60 \%$ biochar $+40 \%$ compost $)$. The use of the first experiment results in the second experiment showed that the application of biocom plus Neosartorya-TM8 (BTM) on an Ultisol soil significantly improved the growth and yield of maize, as well as its the phosphorus uptake and uptake efficiency .
\end{abstract}

Keywords: biochar, phosphate-solubilizing fungi, oil palm empty fruit bunch, Ultisol

\section{INTRODUCTION}

The area of Ultisols in Indonesia reaches 45.8 million ha or $25 \%$ of the land area of Indonesia (Subagyo et al., 2004). In general, the available $\mathrm{P}$ content in Ultisols is low due to $\mathrm{P}$ fixation by $\mathrm{Al}$ and $\mathrm{Fe}$ (Osorio, 2014). The availability of $\mathrm{P}$ in Ultisol can be easily increased by the application of inorganic P fertilizer. However, only a small proportion of the added $\mathrm{P}$ is eventually taken up by the plant and the remainder (almost 75-90\%) is precipitated by $\mathrm{Fe}, \mathrm{Al}$, and $\mathrm{Ca}$ complexes in the soil (Gyaneshwar et al., 2002). The low efficien- cy of P-use of cultivated crops on farms does not only result in larger $\mathrm{P}$ fertilizer applications, but also causes environmental problems, such as water eutrophication (Chang and Yang, 2009; Kang et al., 2011). The low content of soil organic matter in Ultisols (Prasetyo and Suriadikarta, 2006) also causes low soil buffering capacity that results in low fertilizer efficiency. Isgitani et al. (2005) reported that only $5-20 \%$ of the applied inorganic P fertilizer of $150-200 \mathrm{~kg} \mathrm{P}^{-1}$ was taken up by the plants.

One source of organic material commonly used by local farmers to increase the availability 
of $\mathrm{P}$ in Ultisols in Central Kalimantan includes bunches of empty oil palm fruit (Ariani, 2009). This is because the area of oil palm plantation in Central Kalimantan is about 1.09 million ha (Central Bureau of Statistics, 2015). In addition to being a source of organic material, oil palm empty fruit bunches are also habitat for microorganisms, including the P-solubilizing fungi, bacteria, and actinomycetes (Sundara et al., 2002) that are able to convert the unavailable $\mathrm{P}$ to $\mathrm{H}_{2} \mathrm{PO}_{4}{ }^{-}$and $\mathrm{HPO}_{4}{ }^{2-}$ that are available for crops (Coutinho et al., 2012). The phosphate-solubilizing microorganisms that are capable of converting the unavailable $\mathrm{P}$ into available forms for plants can also serve as biological fertilizers to increase the available $\mathrm{P}$ content (Narsian and Patel, 2000; Delvasto, 2006; Khan et al., 2007; Zhu et al., 2012). Many studies have shown that the growth and uptake of $\mathrm{P}$ by plants can be enhanced by the inoculation of phosphate-solubilizing fungi, either through pot experiments (Mittal et al., 2008), or field experiments (Duponnois et al., 2005).

In an earlier study, Ichriani et al. (2017) obtained 4 isolates of phosphate-solubilizing fungi from the compost of oil palm empty fruit bunches that were identified as Acremonium kiliens, Aspergillus oryza, Hymenella Fr., and Neosartorya fischeri. The application of the four phosphate-solubilizing fungi isolates on liquid Pikovskaya medium containing tricalcium phosphate $\left(\mathrm{Ca}_{2}\left(\mathrm{PO}_{4}\right)_{2}\right.$ could increase the available $\mathrm{P}$ by $451 \%, 400 \%$, $216 \%$ and $114 \%$, respectively, on day 5 (Ichriani et al., 2017 ) The phosphate-solubilizing fungi produce organic acid compounds which can dissolve the P compound fixed by the metal compound by forming a complex metal compound (Sharma et al., 2013; Fitriatin et al., 2014).

The application of phosphate-solubilizing fungi on the soil requires a carrier medium as a substrate for the life of the fungi. Suitable biological fertilizer carriers must meet the following criteria: (1) they must be available in powder or granule form; (2) should be able to support the growth and survival of microorganisms, and easily release functional microorganisms into the soil; (3) must have strong moisture absorption capability, good aeration characteristics, and excellent $\mathrm{pH}$ buffering capacity; (4) must be non-toxic and environmentally friendly; (5) should be easily sterilized, manufactured and handled in the field, and have good storage quality; and (6) should be cheap (Stephens and Rask, 2000; Rebah et al., 2002; Rivera-Cruz et al., 2008). Since fungi are commonly found in the areas containing organic substrates, oil palm empty fruit bunches may be used as carrier medium for phosphate-solubilizing fungi. However, the addition of fresh organic matter to the soil can increase carbon emissions into the atmosphere due to the decomposition of organic matter (Widowati et al., 2011). One alternative to reducing the carbon emissions due to decomposition of organic materials and at the same time maintaining soil fertility is with biochar (Crombie et al., 2015). Biochar is the result of biomass heating in pyrolysis installations at temperature of $>700^{\circ} \mathrm{C}$ under low oxygen conditions (Cheng et al., 2007). The physical and chemical properties of biochar depend on raw materials and pyrolysis conditions (Han et al. 2013, Mukome et al. 2013). The aromatic structure of biochar contributes to the long existence of biochar in the soil (Baldock and Smernik, 2002), which makes biochar a material for carbon sequestration, maintain nutrient elements (Mao et al., 2012), and suitable for use as soil amendments (Novak et al., 2009; Spokas et al., 2011). According to Šimanský and Klimaj (2017), biochar is a soil amendment that can increase the soil $\mathrm{pH}$, and the greatest effect on soil $\mathrm{pH}$ is after application of $10 \mathrm{t} \mathrm{ha}^{-1}$ with a combination of $40 \mathrm{~kg}$ of nitrogen $\mathrm{ha}^{-1}$ (Šimanský and Klimaj, 2017). In addition to the potential physical and chemical impacts of biochar on soil productivity, biochar also benefits soil biology, such as selection for plant growth promoting bacteria or fungi (Graber et al., 2010). One of the mechanisms that cause biochar to have a positive impact on soil function is because biochar serves as a protection for fungal hyphae due to its porous nature (Warnock et al., 2007).

Several research results indicate that biochar is used as a solid carrier medium for inoculums of Azospirilum sp. (Kuppusamy et al., 2011), Entorobacter cloacae (Hale et al., 2014), and arbuscular mycorrhizae (Nurbaity et al., 2009). The use of biochar from oil palm empty fruit bunches for microbial carrier media for Bulkhorideria nodosa G.52 and Trichoderma sp. has been performed on several soil types (Ichriani et al., 2016). The mixture of oil palm empty fruit bunch biochar and peat was also used as solid carrier media for Trichoderma harzianum (Kresnawaty et al., 2012). Douds et al. (2014) stated that biochar could be used as a fungus medium in the inoculums production system. Thus, biochar can be used as a carrier medium for phosphate-solubilizing fungi. Collaboration of microbes and biochar 
produced from oil palm empty bunches improves the soil properties (Ichriani et al., 2016). Senoo et al. (2002) reported that compost and biochar carrying agents could maintain the vitality of microorganisms. Therefore, biochar and compost are good carriers for microbial inoculums (Somarathne et al., 2013). However, the information on the use of biochar of oil palm empty fruit bunches as a carrier medium for phosphate-solubilizing fungi is still very limited. The collaboration of oil palm empty fruit bunch biochar and phosphatesolubilizing fungi is expected to aid in the storage and supply of nutrients. The presence of phosphate-solubilizing fungi also helps to increase the availability of $\mathrm{P}$ in Ultisols to improve the crop production. The purpose of this study was to study the effect of phosphate-solubilizing fungi application with biochar and compost carrier media from oil palm empty fruit bunches on the growth and yield of maize grown on an Ultisol from Central Kalimantan.

\section{MATERIALS AND METHODS}

The materials used in this study were an Ultisol, biochar of oil palm empty fruit bunches, compost of oil palm empty fruit bunches, and isolates of phosphate-solubilizing fungi. The compost of oil palm empty fruit bunches was obtained from oil palm plantations PT. Surya Inti Sawit Kahuripan (Makin Group), Parenggean Subdistrict, Kotawaringin Timur District, Central Kalimantan. The soil was collected from farmers' land in Gunung Emas District, Central Kalimantan. The biochar of oil palm empty fruit bunches was made from oil palm empty fruit bunches which was heated pyrolysis at $400^{\circ} \mathrm{C}$ for $6-7$ hours. The characteristics of soil (top soil, $0-30 \mathrm{~cm}$ ) are as follows: clay loam (24\% sand, $47 \%$ silt, $29 \%$ clay), $13.87 \%$ available water content, $\mathrm{pH}\left(\mathrm{H}_{2} \mathrm{O}\right)$ $4.3,0.52 \%$ organic-C, $156.47 \mathrm{ppm}$ total $\mathrm{P}, 2.13$ ppm available $\mathrm{P}, 137.65 \mathrm{ppm}$ total $\mathrm{K}, 15.25 \mathrm{ppm}$ available $\mathrm{K}$, exchangeable cations of $\mathrm{Ca}, \mathrm{Mg}, \mathrm{K}$, $\mathrm{Na}, \mathrm{Al}$ and $\mathrm{H}$, respectively, $1.80,0.45,0.06,0.21$,

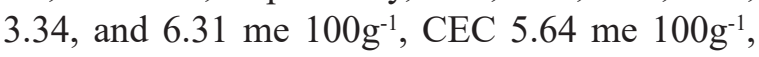
and $45 \%$ base saturation. The characteristics of oil palm empty fruit bunch compost are as follows: $\mathrm{pH}\left(\mathrm{H}_{2} \mathrm{O}\right) 6.7,17.30 \%$, organic $\mathrm{C}, 1.56 \%$ total N, 3,700 ppm total P, 1,100 ppm total K, exchangeable cations of $\mathrm{Ca}, \mathrm{Mg}, \mathrm{K}$, and $\mathrm{Na}$, respec-

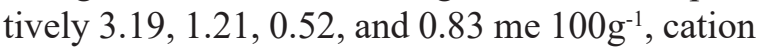

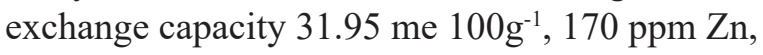

168 ppm Cu, 3.1 ppm Fe, 44 ppm Co, 1190 ppm $\mathrm{Mn}$, and $2.18 \mathrm{ppm} \mathrm{Cd}$. The characteristics of biochar are as follows: $\mathrm{pH} 9.9,61 \% \mathrm{C}, 23.86 \% \mathrm{O}$, $1.78 \% \mathrm{Si}, 1.18 \% \mathrm{Cl}, 10.48 \% \mathrm{~K}$, and $1.5 \% \mathrm{Ca}$.

\section{Experiment 1: Adaptation of phosphate- solubilizing fungi on media of biochar and compost from oil palm empty fruit bunches}

Four isolates of phosphate-solubilizing fungi from Ichriani et al. (2017) i.e. Acremonium (TB1), Aspergillus (TB7), Hymenella (TM1) and Neosartorya (TM8) were inoculated on mixtures of oil palm empty fruit bunch biochar and oil palm empty fruit bunch compost with proportion: $100 \%$ biochar $-0 \%$ compost (B0), $90 \%$ biochar $10 \%$ compost (B1), $80 \%$ biochar $-20 \%$ compost (B2); $70 \%$ biochar $-30 \%$ compost (B3), and $60 \%$ biochar $-40 \%$ compost (B4). Henceforth, the carrier medium will be called 'biocom' (B). The total weight for each biocom carrier medium was $10 \mathrm{~g}$. Prior to the inoculation of the phosphate solubilizing fungi, the 'biocom' was sterilized for 2 hours in boiling water, then after 24 hours, the biocom was reheated for 2 hours. The density of each inoculated phosphate-solubilizing fungi per biocom was $10^{8}$ conidia $\mathrm{mL}^{-1} 10 \mathrm{~g}^{-1}$ of biocom media. The biocom that has been inoculated with phosphate solubilizing fungi was placed in a closed container and placed in a sterile room during the trial period. Twenty treatments (four isolates and five biocoms) were prepared in a completely randomized design with four replicates. The ability of the phosphate-solubilizing fungi to survive on the biocom medium was observed by observing the population of the fungi by the method of pouring and growing in PDA (Potato Dextrose Agar) medium at 2, 4, 8, 12 and 16 weeks after inoculation. The biocom media which had the highest population of phosphate-solubilizing fungi at the end of the observation period (week 4) was observed for microstructure using Scanning Electron Microscophy-Energy Dispersive X-ray (SEM-EDX) method. The measurements of $\mathrm{pH}$ and organic $\mathrm{C}$ of the carrier media were carried out at 4 and 8 weeks after inoculation.

\section{Experiment 2: Effect of biocom + phosphate- solubilizing fungi application on maize growth}

The treatments tested for maize plant growth were control (T), biochar (B), biocom 60:40 plus Aspergillus-TB7 (BTB), and biocom 70:30 plus 
Neosartorya-TM8 (BTM). The treatments were arranged in a completely randomized design with five replicates. The dosage used in each polybag was the $12 \mathrm{~kg}$ of soil, basic fertilizer $(200 \mathrm{~kg}$ $\mathrm{N} \mathrm{ha}^{-1}, 150 \mathrm{~kg} \mathrm{P}_{2} \mathrm{O}_{5} \mathrm{ha}^{-1}, 150 \mathrm{~kg} \mathrm{~K}_{2} \mathrm{O} \mathrm{ha}^{-1}, 10 \mathrm{ppm}$ $\mathrm{Mg}, 10$ ppm Ca, 10 ppm Zn, 6 ppm Cu, 0.9 ppm B, and 0.9 ppm Mo) (Santi and Goenardi, 2012), $15 \mathrm{t}$ biochar $(\mathrm{B}) \mathrm{ha}^{-1}$, or $15 \mathrm{t}$ biocom + FPF (BTB or BTM) ha-1 (Sukartono et al. 2011, Uzoma et al. 2011). The content of $P$ in the $P$ fertilizer used is $17.87 \%$. The observations consisted of vegetative and generative growth indicators, biomass, and $\mathrm{P}$ uptake by maize. The $\mathrm{P}$ uptake $\left(\mathrm{g} \mathrm{plant}^{-1}\right)$ was calculated based on total P-content in maize plant biomass. Total $\mathrm{P}$ in plant was determined by $\mathrm{HNO}_{3}-\mathrm{HClO}_{4}$ wet extraction and continued measurements with spectrophotometer at $693 \mathrm{~nm}$ wavelength. The data obtained were subjected to analysis of variance followed by Duncan's Multiple Range Test (DMRT) at 0.05 level of significance. The efficiency of $P$ fertilization (EhP) was calculated with the formula of Dobermann (2007): Ehp $=[(\mathrm{SPp}-\mathrm{SKp}) / \mathrm{Hpp}] \times 100 \%$, where Ehp is the nutrient uptake efficiency of P, SPp is the uptake of $P$ nutrient in the plant fertilized with $\mathrm{P}, \mathrm{SKp}$ is the uptake of $\mathrm{P}$ nutrient in plant not fertilized with $\mathrm{P}$, and HPp is the nutrient content of $\mathrm{P}$ in the P fertilizer given to the plant.

\section{RESULTS AND DISCUSSION}

Adaptation of phosphate solubilizing fungi in oil palm empty fruit bunch biocom media

Isolates of phosphate solubilizing fungi applied to carrier media in the form of oil empty palm empty bunch biocom had different life and growing ability. The results of observation of the population involving each carrier medium $2,4,8$, 12 , and 16 weeks after inoculation are presented in Figure 1. The highest population of Acremonium-TB1 and Hymenella-TM1 was achieved at 8 weeks after inoculation, while the highest population of Aspergillus-TB7 and NeosartoryaTM8 was achieved 4 weeks after inoculation. However, the Aspergillus-TB7 and NeosartoryaTM8 populations within 4 weeks of inoculation were higher than those of Acremonium-TB1 and Hymenella-TM1. This shows that AspergillusTB7 and Neosartorya-TM8 are more capable of living and adapting in solid carrier media of oil palm empty fruit bunch biocom. One of the mechanisms that cause biochar to have a positive impact on function is because biochar serves as a hiding place for fungal hyphae due to its porous nature (Warnock et al., 2007). Hadi et al. (2014) reported that biochar applications into the soil increased the fungi population by more than $22.2 \%$. The phosphate-solubilizing Aspergillus species have been studied as the most highly adapted fungi to the growing environment and thus have a high ability of increasing the availability of soil $\mathrm{P}$ for improving the plant growth (El-Azouni, 2008; Mittal et al., 2008; Ogbo, 2010; Jain et al., 2012). After experiencing the highest population, there was a trend of isolate population decline. At 16 weeks after inoculation, Aspergillus-TB7 and Neosartorya-TM8 populations decreased as in the period of 2 weeks after inoculation.

The carrier medium containing only biochar without compost (B0) did not provide a good growth medium for all isolates, since it had the smallest population of phosphate-solubilizing fungi. The low nutrients contained in biochar media alone caused improper growth of the fungi. The changes of cellulose and lignin structure of oil palm empty fruit bunch into complex structures in the form of crystalline structures and $\mathrm{C}=\mathrm{C}$ aromatic rings might have occurred during the process of slow pyrolysis of fresh oil palm empty fruit bunch material into biochar. According to Joseph et al. (2010), it is difficult for fungal organisms are to use carbon compounds in very complex forms such as the crystal and aromatic structures. The result of gas chromatographymass spectrometry (GCMS) analysis showed that oil palm empty fruit bunch biochar contained organic compound with functional group of $\mathrm{C}=\mathrm{C}$ aromatic ring structure. This was marked by the appearance of peak on the wave number of $1500-1600 \mathrm{~cm}^{-1}$ which might indicate the presence of $\mathrm{C}=\mathrm{C}$ aromatic ring group. This result was also supported by the analysis of oil palm empty fruit bunch biochar with GCMS that obtained organic compounds suspected as cyclopropane $(15.51 \%)$ and cycloheptatriene (12.04\%). Therefore, carrier media combined with oil palm empty fruit bunch compost showed a higher phosphate-solubilizing fungi population, since compost contained simple compounds that could be used as nutrients by phosphate-solubilizing fungi. Acremonium-TB1 seemed to be more suited to the composition of biocom media of 80:20 (B2), whereas Aspergillus-TB7 had the highest population with 60:40 (B4) biocom compositions with slower population decline than other com- 
a)

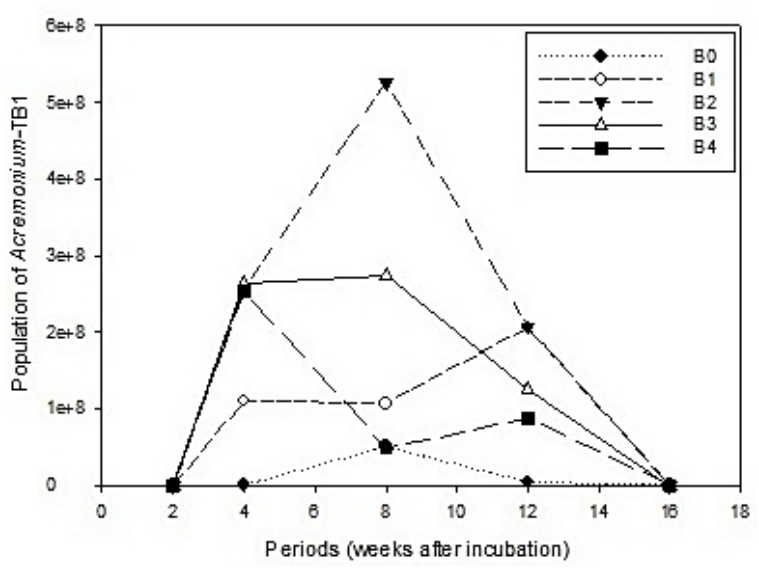

c)

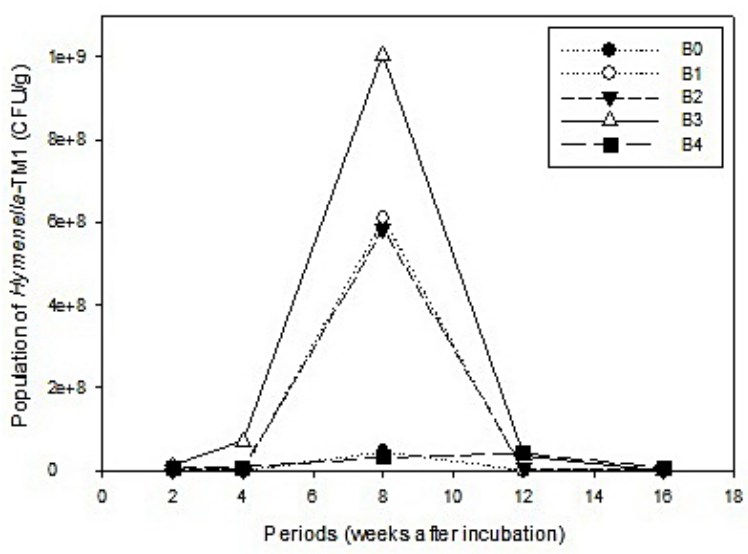

b)

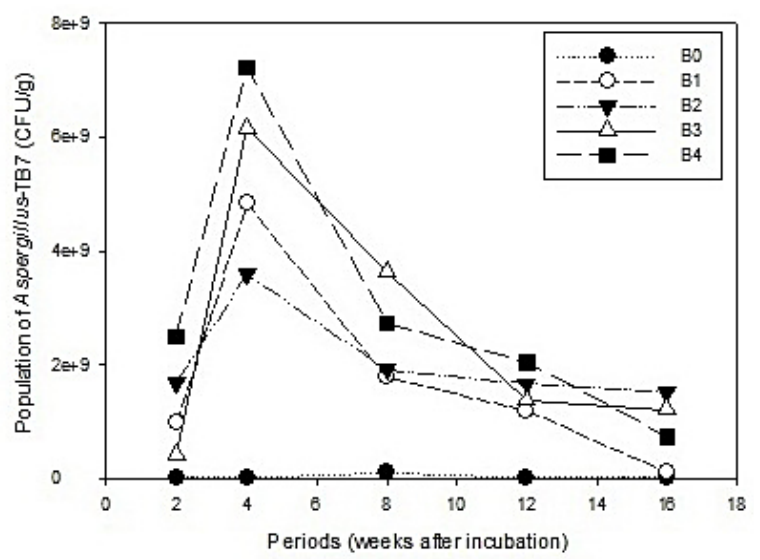

d)

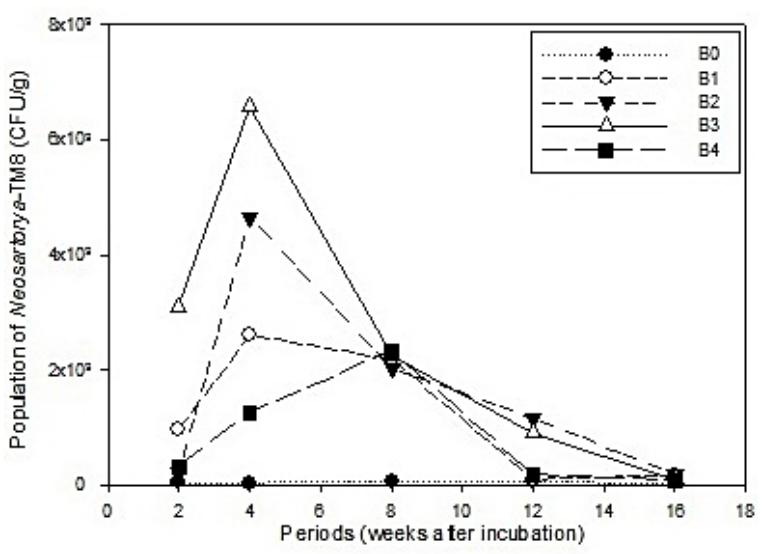

Figure 1. The survival of Acremonium-TB1 (A), Aspergillus-TB7 (B), Hymenella-TM1 (C), and NeosartoryaTM8, (D) for 2-6 weeks in several biocom formulations

positions. Hymenella-TM1 and Neosartorya-TM 8 were more suited to the 70:30 biocom media composition (B3) with the highest population in each isolate. The population decline in the 70:30 biocom media composition was also slower than the composition of other biocom media. Compost contains microaggregate with micropore structure (Somarathne et al., 2013). The materials having a micropore structure such as charcoal will be good carriers for soil inoculums (Senoo et al., 2002). Carrier media of compost and biochar can maintain the vitality of microorganisms (Senoo et al., 2002). Therefore, biochar and compost are good carriers for microbial inoculums (Somarathne et al., 2013). Figure 2 shows the results of microstructure analysis of oil palm empty fruit bunch biochar inoculated with Aspergillus-TB7 and Neosartorya-TM8.

The effect of adding oil palm empty fruit bunch compost onto oil palm empty fruit bunch biochar did not linearly increase the population of inoculated isolates of phosphate-solubilizing fungi. For Aspergillus-TB7, the increase in the proportion of oil palm empty fruit bunch compost was accompanied by an elevated phosphate-solubilizing fungi population. However, for Hymenella-TM1 and Neosartorya-TM8, the increase of phosphate solubilizing fungi population was only up to the B3 (biochar 70\%: 30\% compost) and in the proportion of $40 \%$ compost, the population of both isolates decreased. The results of analyzes pertaining to $\mathrm{pH}$ and organic $\mathrm{C}$ of biocom media at 4 and 8 weeks showed that the decrease in the proportion of oil palm empty fruit bunch biochar in the media (decreasing the proportion of oil palm empty fruit bunch compost) has decreased the $\mathrm{pH}$ of the biocom medium (Table 1). In addition, the $\mathrm{pH}$ value of each biocom media formulation decreased 8 weeks after inoculation, compared with the $\mathrm{pH}$ value of biocom medium 4 weeks after inoculation.

The addition of oil palm empty fruit bunch compost to oil palm empty fruit bunch biochar helped in the adaptation of phosphate-solubiliz- 
a)

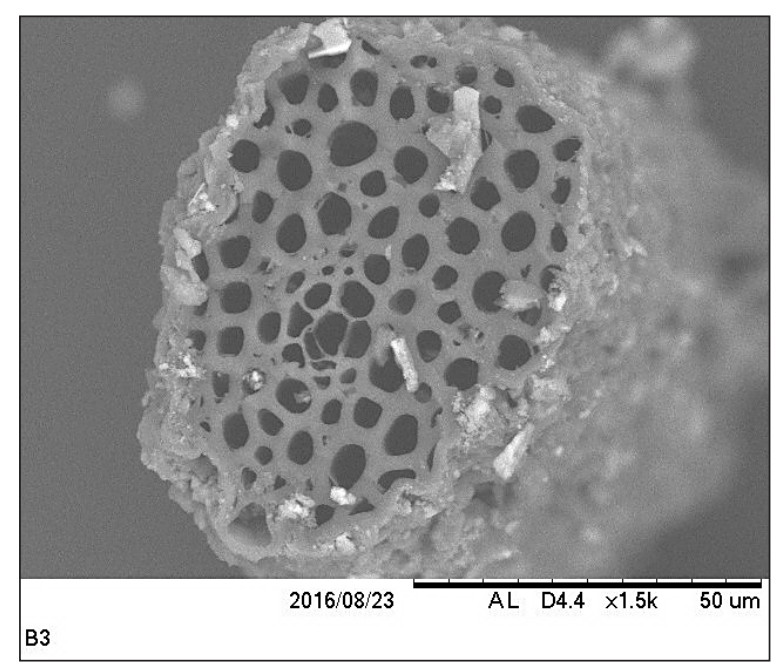

b)

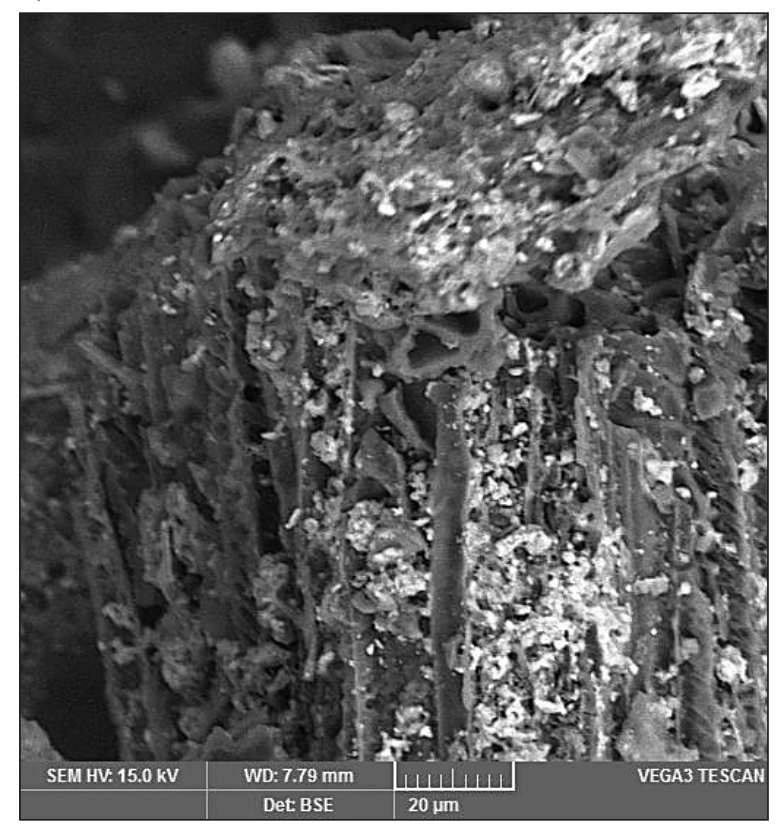

c)

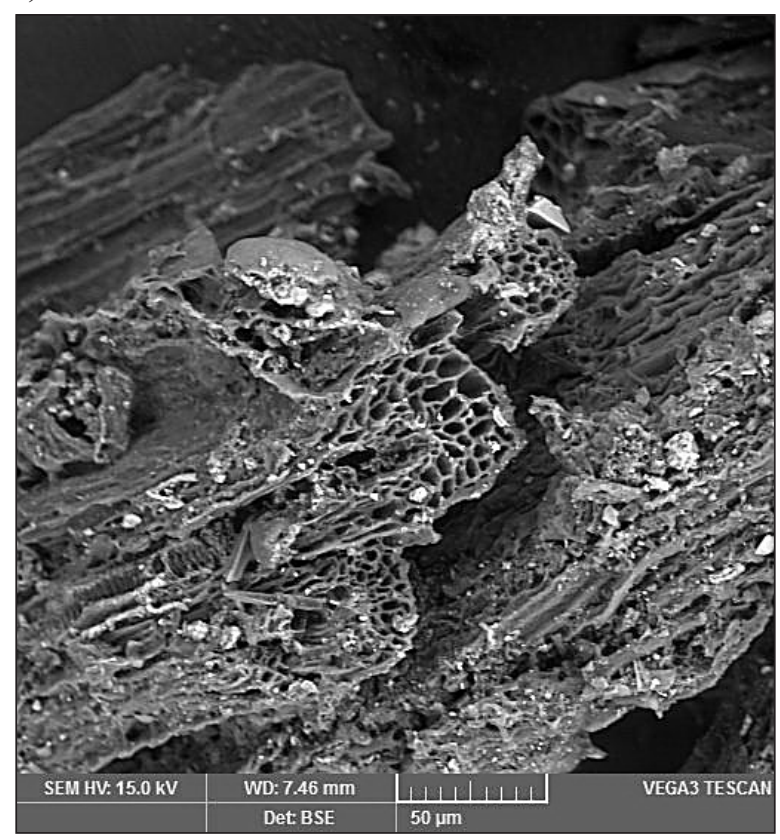

Figure 2. Microstructures (SEM EDX analysis) (A) biochar of oil palm fruit empty bunches; (B) biocom 60:40 (B4) plus Aspergillus-TB7; and (C) biocom 70:30 (B3) plus Neosartorya-TM8

ing fungi to oil palm empty fruit bunch biochar media. Although the content of organic-C media of biocom media was relatively unchanged.

\section{Effect of biocom + phosphate solubilizing- fungi application on maize growth and $P$ uptake efficiency}

The application of oil palm empty fruit bunch biocom plus phosphate-solubilizing fungi significantly affected the growth and yield of maize as well as the $\mathrm{P}$ uptake by maize (Table 2 ). The significant effect of biochar (B) treatment on plant vegetative component (plant height and number of leaves) was seen faster 2 weeks after planting. However, after 2 weeks, the treatment of oil palm empty fruit bunch biocom plus phosphate-solubilizing fungi showed a better influence on the plant growth. The results of Duncan's Multiple Range Test at 5\% level showed that when biochar (B) and biocom plus phosphate-solubilizing fungi (BTB and BTM) 
Table 1. $\mathrm{pH}$ and organic $\mathrm{C}$ of biocom media 4 and 8 weeks after inoculation

\begin{tabular}{|c|c|c|c|c|}
\hline \multirow{2}{*}{ Biocom } & \multicolumn{2}{|c|}{$\mathrm{pH}$} & \multicolumn{2}{|c|}{ Organic C (\%) } \\
\hline & 4 weeks & 8 weeks & 4 weeks & 8 weeks \\
\hline \multicolumn{5}{|c|}{ Acremonium-TB1 } \\
\hline $\mathrm{B} 0+\mathrm{TB} 1$ & 10.13 & 10.12 & 8.13 & 8.72 \\
\hline $\mathrm{B} 1+\mathrm{TB} 1$ & 10.07 & 10.03 & 8.36 & 7.83 \\
\hline $\mathrm{B} 2+\mathrm{TB} 1$ & 10.08 & 9.87 & 8.77 & 7.87 \\
\hline $\mathrm{B} 3+\mathrm{TB} 1$ & 9.90 & 9.84 & 8.96 & 8.40 \\
\hline B4+TB1 & 9.83 & 9.70 & 10.56 & 10.56 \\
\hline \multicolumn{5}{|c|}{ Hymenella-TM1 } \\
\hline B0+TM1 & 10.19 & 10.17 & 9.54 & 8.46 \\
\hline $\mathrm{B} 1+\mathrm{TM} 1$ & 10.07 & 9.98 & 10.96 & 7.98 \\
\hline B2+TM1 & 10.01 & 9.85 & 9.39 & 9.27 \\
\hline $\mathrm{B} 3+\mathrm{TM} 1$ & 9.97 & 9.81 & 8.28 & 8.52 \\
\hline B4+TM1 & 9.83 & 9.65 & 9.61 & 9.68 \\
\hline \multicolumn{5}{|c|}{ Aspergillus-TB7 } \\
\hline $\mathrm{B} 0+\mathrm{TB} 7$ & 10.54 & 10.08 & 10.40 & 6.82 \\
\hline $\mathrm{B} 1+\mathrm{TB} 7$ & 10.49 & 10.00 & 10.68 & 7.90 \\
\hline $\mathrm{B} 2+\mathrm{TB} 7$ & 10.42 & 9.96 & 8.20 & 8.11 \\
\hline $\mathrm{B} 3+\mathrm{TB} 7$ & 10.34 & 9.83 & 10.97 & 9.99 \\
\hline $\mathrm{B} 4+\mathrm{TB} 7$ & 10.13 & 9.65 & 9.62 & 9.87 \\
\hline \multicolumn{5}{|c|}{ Neosartorya-TM8 } \\
\hline $\mathrm{B} 0+\mathrm{TM} 8$ & 10.00 & 10.00 & 10.10 & 9.27 \\
\hline $\mathrm{B} 1+\mathrm{TM} 8$ & 10.07 & 10.05 & 9.77 & 7.68 \\
\hline B2+TM8 & 10.04 & 9.92 & 9.44 & 9.44 \\
\hline B3+TM8 & 10.04 & 9.87 & 10.59 & 7.75 \\
\hline B4+TM8 & 9.77 & 9.80 & 11.35 & 10.46 \\
\hline
\end{tabular}

Table 2. Effect of application of biocom + phosphate-solubilizing fungi on maize growth

\begin{tabular}{|c|c|c|c|c|}
\hline \multirow{2}{*}{ Treatments } & \multicolumn{4}{|c|}{ Plant Height $(\mathrm{cm})$} \\
\hline & 2 weeks & 4 weeks & 6 weeks & 8 weeks \\
\hline $\mathrm{T}$ & 33.34 & $48.36^{a}$ & $102.52^{a}$ & $164.58^{a}$ \\
\hline B & 34.86 & $77.22^{b}$ & $147.60^{b}$ & $198.06^{b}$ \\
\hline BTB & 37.68 & $82.98^{d}$ & $161.70^{d}$ & $207.10^{c}$ \\
\hline BTM & 35.22 & $79.94^{\circ}$ & $154.86^{c}$ & $211.88^{d}$ \\
\hline \multirow{2}{*}{ Treatments } & \multicolumn{4}{|c|}{ Number of Leaves } \\
\hline & 2 weeks & 4 weeks & 6 weeks & 8 weeks \\
\hline$T$ & 4.00 & $4.80^{a}$ & $5.40^{a}$ & $9.20^{a}$ \\
\hline$B$ & 4.00 & $5.60^{b}$ & $7.40^{b}$ & $11.60^{b}$ \\
\hline BTB & 4.00 & $6.40^{c}$ & $8.01 \mathrm{c}$ & $12.60^{c}$ \\
\hline BTM & 4.00 & $6.20^{\circ}$ & $8.00^{c}$ & $12.80^{\circ}$ \\
\hline \multirow{2}{*}{ Treatments } & \multicolumn{4}{|c|}{ Stem Diameter $(\mathrm{mm})$} \\
\hline & 2 weeks & 4 weeks & 6 weeks & 8 weeks \\
\hline $\mathrm{T}$ & $1.52^{\mathrm{a}}$ & $3.62^{a}$ & $7.54^{\mathrm{a}}$ & $8.92^{a}$ \\
\hline $\mathrm{B}$ & $2.38^{c}$ & $6.82^{b}$ & $11.48^{b}$ & $14.94^{b}$ \\
\hline BTB & $2.22^{b c}$ & $7.22^{c}$ & $13.12^{\mathrm{d}}$ & $15.56^{c}$ \\
\hline BTM & $2.08^{b}$ & $7.26^{c}$ & $11.82^{c}$ & $15.80^{d}$ \\
\hline
\end{tabular}

Remarks: numbers followed by the same letters in each column indicate no significant different at 5\% Duncan's Multiple Range Test.

treatments were compared with control $(\mathrm{T})$, the above-mentioned ameliorant materials had very significant effects on vegetative, generative, biomass and $\mathrm{P}$ uptake by maize. At the begin- ning of the growth of maize (2 weeks), the application of biochar alone (B) resulted in good and fast growth of maize. At 4-6 weeks, the biocom plus Aspergillus-TB7 (BTB) treatment 
gave the best growth performance and biomass of maize even though its $\mathrm{P}$ uptake was lower than that of $\mathrm{P}$ in biocom plus Neosartorya-TM8 (BTM) treatment. However, at 8 weeks, the performance of maize (growth, biomass, and $\mathrm{P}$ uptake) as well as the yield components with the BTM treatment was the best. At 4 weeks, the biocom plus phosphate-solubilizing fungi provided a $100-200 \%$ increase in the $\mathrm{P}$ uptake compared with the control treatment. Generally, biological fertilizer in carrier media increases the plant growth more effectively than free cell biofertilizer; this is because carriers protect the functional microbes from soil or climate stress (Jain et al., 2010). Mechanisms such as the production of phytohormones, vitamins or amino acids may be involved in the effect of microorganisms on phosphate dissolution (Chakkaravarthy et al., 2010).

A number of theories explain the mechanism of inorganic phosphate dissolution i.e. the production of mineral dissolving compounds such as organic acids, siderophores, protons, hydroxyl ions, and $\mathrm{CO}_{2}$ (Rodríguez and Fraga, 1999; Sharma et al., 2013). The organic acids produced together with carboxyl and hydroxyl ion cations then chelate or reduce the $\mathrm{pH}$ to release P (Seshachala and Tallapragada, 2012). Organic acids are produced in the periplasmic chamber by direct oxidation pathway (Zhao et al., 2014). The excretion of these organic acids is accompanied by a decrease in $\mathrm{pH}$, resulting in acidification of microbial cells and its surroundings, so that the $\mathrm{P}$ ions are released by substitution of $\mathrm{H}^{+}$to $\mathrm{Ca}^{2+}$ (Goldstein, 1994). Another mechanism of dissolving phosphate minerals by microorganisms is the production of inorganic acids (such as sulfuric acid, nitrate, and carbonate) and the production of chelating agents (Alori et al., 2017). The increase in the percentage of $\mathrm{P}$ uptake is in line with the elevated plant biomass and supports the increase of crop production. The fertilization efficiency of $\mathrm{P}$ fertilizer is based on the efficiency of $\mathrm{P}$ nutrient uptake. In this study, $32.6 \%$ increase of the $P$ uptake efficiency was observed for biocom plus Aspergillus-TB7 (BTB) and 42.5\% increase of the $\mathrm{P}$ uptake efficiency was observed for biocom plus Neosartorya-TM8 (BTM), while the application of biochar alone (B) only resulted in $2.5 \%$ increase of the $\mathrm{P}$ uptake efficiency. This suggests that the application of biochar plus phosphatesolubilizing fungi, either Aspergillus-TB7 or Neosartorya-TM8, could improve the P uptake efficiency to meet the P nutrient needs for maize. In addition, the use of biochar in fungi carrier positively contributed to the improved availability of micronutrients for plants and water balance in the soil, because biochar has a high porosity (Ścisłowska et al., 2015).

Table 3. Effect of application of biocom + phosphate-solubilizing fungi on yield components

\begin{tabular}{|c|c|c|c|c|c|c|c|}
\hline \multirow[t]{2}{*}{ Treatments } & \multicolumn{2}{|l|}{$\begin{array}{l}\text { Shoot Dry } \\
\text { Weight (g) }\end{array}$} & \multicolumn{2}{|l|}{$\begin{array}{l}\text { Root Dry } \\
\text { Weight (g) }\end{array}$} & \multirow{2}{*}{$\begin{array}{l}\text { Fresh Weight } \\
\text { of Cob } \\
\text { with Husk (g) }\end{array}$} & $\begin{array}{l}\text { Fresh } \\
\text { Weight } \\
\text { (g) }\end{array}$ & \begin{tabular}{|l} 
Dry \\
Weight \\
(g)
\end{tabular} \\
\hline & 4 weeks & 8 weeks & 4 weeks & 8 weeks & & \multicolumn{2}{|c|}{ Cob without husk } \\
\hline$T$ & $8.76^{a}$ & $57.58^{a}$ & $5.07^{a}$ & $10.03^{a}$ & $153.58^{a}$ & $97.48^{a}$ & $31.09^{a}$ \\
\hline B & $11.73^{b}$ & $98.54^{\mathrm{b}}$ & $6.68^{b}$ & $16.37^{b}$ & $221.56^{b}$ & $154.60^{b}$ & $46.07^{b}$ \\
\hline BTB & $13.59^{c}$ & $133.08^{c}$ & $7.91^{d}$ & $19.36^{d}$ & $266.92^{c}$ & $200.58^{c}$ & $60.58^{c}$ \\
\hline BTM & $11.95^{b}$ & $150.94^{d}$ & $6.76^{c}$ & $17.82^{c}$ & $277.12^{d}$ & $210.44^{d}$ & $65.42^{d}$ \\
\hline
\end{tabular}

Remarks: numbers followed by the same letters in each column indicate no significant different at 5\% Duncan's Multiple Range Test.

Table 4. Effect of application of biocom + phosphate-solubilizing fungi on P uptake and efficiency of P uptake by maize

\begin{tabular}{|c|c|c|c|c|}
\hline \multirow{2}{*}{ Treatments } & \multicolumn{2}{|c|}{$\mathrm{P}$ uptake by Maize Shoot $\left(\mathrm{g} \mathrm{plant}^{-1}\right)$} & \multicolumn{2}{|c|}{ Efficiency of $\mathrm{P}$ uptake $\mathrm{P}(\%)$} \\
\cline { 2 - 5 } & 4 weeks & 8 weeks & 4 weeks & 0.0 \\
\hline T & $0.06^{\mathrm{a}}$ & $0.64^{\mathrm{a}}$ & 1.3 & 0.0 \\
\hline B & $0.13^{\mathrm{b}}$ & $1.44^{\mathrm{b}}$ & 3.1 & 32.6 \\
\hline BTB & $0.22^{\mathrm{c}}$ & $2.34^{\mathrm{c}}$ & 3.5 & 42.5 \\
\hline BTM & $0.24^{\mathrm{d}}$ & $2.85^{\mathrm{d}}$ & weeks \\
\hline
\end{tabular}

Remarks: numbers followed by the same letters in each column indicate no significant different at 5\% Duncan's Multiple Range Test. 


\section{CONCLUSION}

The phosphate-solubilizing fungi that were able to adapt to biocom carrier media were Aspergillus-TB7 with 60:40 biocom proportions and Neosartorya-TM8 with 70:30 biocom proportions. The performance of maize growth and $\mathrm{P}$ fertilization efficiency of maize could be improved by applying biocom plus phosphate-solubilizing fungi. Biocom plus Neosartorya-TM8 (BTM) application on an Ultisol of Central Kalimantan provided the best maize growth, maize yield, $\mathrm{P}$ uptake by maize, and $\mathrm{P}$ fertilization efficiency.

\section{Acknowledgements}

The authors thank the Ministry of Research, Technology and Higher Education, financial support to carry out this study. The authors also gratefully acknowledge PT. Surya Inti Sawit Kahuripan, Central Kalimantan for providing oil palm empty fruit bunch for this study. Very valuable technical assistance and support from staff of Soil Laboratory of Brawijaya University and Lambung Mangkurat University are highly appreciated.

\section{REFERENCES}

1. Alori E.T., Glick B.R., Babalola O.O. 2017 Microbial phosphorus solubilization and its potential for use in sustainable agriculture. Frontiers in Microbiology, 8, 971.

2. Ariani E. 2009. A test of NPK Mutiara fertilizer of 16:16:16 and various types of mulch on yield of pepper plant (Capsicum annum L.). Sagu, 8(1), 5-9 (in Indonesian).

3. Baldock J.A., Smernik R.J. 2002. Chemical composition and bioavailability of thermally altered Pinus resinosa (Red Pine) wood. Organic Geochemistry, 33, 1093-1109.

4. Central Bureau of Statistics. 2015. Statistics of Indonesian Oil Palm 2014. Jakarta (in Indonesian).

5. Chakkaravarthy V.M., Arunachalam R., Vincent S., Paulkumar K., Annadurai G. 2010. Biodegradation of tricalcium phosphate by phosphate solubilizing bacteria. Journal of Biological Sciences, 10(6), 531-535.

6. Chang C.H., Yang S. 2009. Thermo-tolerant phosphate-solubilizing microbes for multi-functional biofertilizer preparation. BioresourceTechnology, 100, 1648-1658.

7. Cheng C.H., Lehmann J., Engelhard M.H. 2007.
Natural oxidation of black carbon in soils: changes in molecular form and surface charge along a climosequence. Geochimica et Cosmochimica Acta, 72, 1598-1610.

8. Coutinho F., Yano-Melo A.M., Felix W. 2012. Solubilization of phosphates in vitro by Aspergillus spp. and Penicillium spp. Ecological Engineering, $42,85-89$.

9. Crombie K., Mašek O., Cross A., Sohi S. 2015. Biochar-synergies and trade-offs between soil enhancing properties and $\mathrm{C}$ sequestration potential. GCB Bioenergy, 7(5), 1161-1175.

10. Delvasto P., Valverde A., Ballester A., Igual J.M., Muñoz J.A., González F., Blázquez M.L., García C. 2006. Characterization of brushite as a re-crystallization product formed during bacterial solubilization of hydroxyapatite in batch cultures. Soil Biology and Biochemistry, 38, 2645-2654.

11. Dobermann, A. 2007. Nutrient use efficiency. Measurement and management. In: Kraus A., Isherwood K., Heffer P. (Eds.), Fertilizers Best Management Practices. Proc. International fertilizer Industry Association, Brussels, Belgium, 7-9 March 2007, 1-22.

12. Douds Jr D.D., Lee J., Uknalis J., Boateng A.A., Ziegler-Ulsh C. 2014. Pelletized Biochar as a carrier for AM Fungi in the on-farm system of inoculums production in compost and vermiculite mixtures. Compost Science \& Utilization, 22, 253-262

13. Duponnois R., Colombet A., Hien V., Thioulouse J. 2005. The mycorrhizal fungus Glomus intraradices and rock phosphate amendment influence plant growth and microbial activity in the rhizosphere of Acacia holosericea. Soil Biology and Biochemistry, 37, 1460-1468.

14. El-Azouni I.M. 2008. Effect of phosphate solubilizing fungi on growth and nutrient uptake of soybean (Glycine max L.) plants. Journal of Applied Sciences Research, 4(6), 592-598.

15. Fitriatin B.N., Yuniarti, A., Turmuktini T., Ruswandi F.K. 2014. The effect of phosphate solubilizing microbe producing growth regulators on soil phosphate, growth and yield of maize and fertilizer effiency on Ultisol. Eurasian Journal of Soil Science, 3(2), 101-107.

16. Goldstein A.H. 1994. Involvement of the quinoprotein glucose dehydrogenase in the solubilization of exogenous phosphates by gram-negative bacteria. In Phosphate in Microorganisms: Cellular and Molecular Biology, eds Torriani-Gorini A., Yagil E. and Silver S. ASM Press, Washington, DC.

17. Graber E.R., Harel Y.M., Kolton M., Cytryn E., Silber A., David D.R., Tsechansky L., Borenshtein M., Elad Y. 2010. Biochar impact on development and productivity of pepper and tomato grown in fertigated soilless media. Plant and Soil, 337, 481-496. 
18. Gyaneshwar P., Naresh K.G., Parekh L.J., Poole P.S. 2002. Role of soil microorganisms in improving P nutrition of plants. Plant and Soil, 245, 83-93.

19. Hadi A., Gafur, A., Udiantoro, Mukhlis. 2014. Design of Pyrolysis Installation of Agricultural Waste in the Framework of Minimization of Greenhouse Gas Emissions from Wetlands. Proc. the 5th SNST of 2014. Faculty of Engineering, Wahid Hasyim University, Semarang. ISBN 978-602-999334-3-7. pp 1-9 (in Indonesian).

20. Hale L., Luth M., Kenney R., Crowley D. 2014. Evaluation of pinewood biochar as a carrier of bacterial strain Enterobacter cloacae UW5 for soil inoculation. Applied Soil Ecology, 84, 192-199.

21. Han X., Boateng A.A, Qi P.X., Lima I.M., Chang J. 2013. Heavy metal and phenol adsorptive properties of biochars from pyrolyzed switch grass and woody biomass in correlation with surface properties. Journal of Environmental Management, 118, 196-204.

22. Ichriani G.I., Nion Y.A., Chotimah H.E.N.C., Jemi R. 2016. Utilization of oil palm empty bunches waste as biochar-microbes for improving availibity of soil nutrients. Journal of Degraded and Mining Lands Management, 3(2), 517-520.

23. Ichriani G.I., Syekhfani, Nuraini Y., Handayanto E. 2017. Solubilization of inorganic phosphate solubilizing fungi isolated from oil palm empty fruit bunches of Central Kalimantan. Bioscience Research, 14(3), 705-712

24. Isgitani M., Kabirun S., Siradz S.A. 2005. The effect of bacterial solvent inoculation of phosphate on the growth of shorgum on various P content of soil. Journal of Soil Science and Environment, 5, 48-54 (in Indonesian).

25. Jain R., Saxena J., Sharma V. 2010. The evaluation of free and encapsulated Aspergillus awamori for phosphate solubilization in fermentation and soilplant system. Applied Soil Ecology, 46, 90-94.

26. Jain R., Saxena J., Sharma V. 2012. Effect of phosphate-solubilizing fungi Aspergillus awamori S29 on mungbean (Vigna radiata cv. RMG 492) growth. Folia Microbiologica, 57, 533-540.

27. Joseph S.D., Camps-Arbestain M., Lin Y., Munroe P., Chia C.H., Hook J., Zwieten L., Kimer S., Cowie A., Singh B.P., Lehmann J., Foidl N., Semrnik R.J., Amonette J.E. 2010. An investigation into the reactions of biochar in soil. Soil Research, 48(7), 501-515.

28. Kang J., Amoozegar A., Hesterberg D., Osmond D.L. 2011. Phosphorus leaching in a sandy soil as affected by organic and incomposted cattle manure. Geoderma, 161, 194-201.

29. Khan M.S., Zaidi A., Wani P.A. 2007. Role of phosphate-solubilizing microorganisms in sustainable agriculture-A review. Agronomy for Sustainable Development, 27, 29-43.
30. Kresnawaty I., Budiani A., Darmono T.W. 2012. Population dinamic of Trichoderma harzianum DT38 on mixture of empty fruit bunches of oil palm (EFBOP) biochar and peat. Menara Perkebunan, 80(1), 17-24 (in Indonesian).

31. Kuppusamy S., Krishnan P.S., Kumutha K., French J., Carlos G.E., Toefield B. 2011. Suitability of UK and Indian source Acacia wood based biochar as a best carrier material for the preparation of Azospirillum inoculum. International Journal of Biotechnology, 4, 582-88.

32. Mao J.D., Johnson, R.L., Lehman, J., Olk D.C., Neves E.G., Thompson M.L., Schmidt-Rohr K. 2012. Abundant and stable char residues in soils: implications for soil fertility and carbon sequestration. Environmental Science and Technology, 46, 9571-9576.

33. Mittal V., Singh O., Nayyar H., Kaur J., Tewari R. 2008. Stimulatory effect of phosphate-solubilizing fungal strains (Aspergillus awamori and Penicillium citrinum) on the yield of chickpea (Cicer arietinum L. cv. GPF2). Soil Biology and Biochemistry, 40, 718-727.

34. Mukome F.N.D., Zhang X., Silva L.C.R., Six J., Parikh. S.J 2013. Use of chemical and physical characteristics to investigate trends in biochar feedstocks. Journal of Agriculture and Food Chemistry, 61, 2196- 2204.

35. Narsian V., Patel H.H. 2000. Aspergillus aculeatus as a rock phosphate solubilizer. Soil Biology and Biochemistry, 32, 559-565.

36. Novak J.M., Busscher W.J., Laird D.L., Ahmedna M., Watts D.W., Niandou M.A.S. 2009. Impact of biochar amendment on fertility of a Southeastern Coastal Plain soil. Soil Science, 174, 105-112.

37. Nurbaity A., Herdiyantoro D., Mulyani O. 2009. The use of organic matter as a carrier of innoculant of arbuscular mycorrhizal fungi. Journal of Biology, Padjadjaran University, 13(1), 17- 11 (in Indonesian).

38. Ogbo F.C. 2010. Conversion of cassava wastes for biofertilizer production using phosphate solubilizing fungi. Bioresource Technology,101, 4120-4124.

39. Osorio N.W., Habte M. 2014. Soil phosphate desorption induced by a phosphate solubilizing fungus. Communications in Soil Science and Plant Analysis, 45(4), 451-460

40. Prasetyo B.H., Suriadikarta D.A. 2006. The characteristics, potential, and technology of Ultisol management for agricultural development in Indonesia. Journal of Agricultural Research and Development, 25(2), 39-47 (in Indonesian).

41. Rebah F.B., Tyagi R.D., Prevost D. 2002. Wastewater sludge as a substrate for growth and carrier for rhizobia, the effect of storage conditions on sur- 
vival of Sinorhizobium meliloti. Bioresource Technology, 831, 45-51.

42. Rivera-Cruz M.C., Narcía A.T., Ballona G.C., Kohler J., Caravaca F., Roldán A. 2008. Poultry manure and banana waste are effective biofertilizer carriers for promoting plant growth and soil sustainability in banana crops. Soil Biology and Biochemistry, 40, 3092-3095.

43. Rodríguez H., Fraga R. 1999. Phosphate solubilizing bacteria and their role in plant growth promotion. Biotechnology Advances, 17, 319-339.

44. Santi L.P., Goenadi D.H. 2012. Utilization of biochar from oil palm shells as an aggregate feeding microbial material. Buana Sains, 12(1), 7-14 (in Indonesian).

45. Ścisłowska M., Włodarczyk R., Kobyłecki R., Bis Z. 2015. Biochar to improve the quality and productivity of soils. Journal of Ecological Engineering, 16(3), 31-35

46. Senoo K., Keneko M., Taguchi R., Murata J., Santasup C., Tanaka A., Obata H. 2002. Enhanced growth and nodule occupancy of red kidney bean and soybean inoculated with soil aggregate-based inoculant. Soil Science and Plant Nutrition, 48(2), 251-259.

47. Seshachala U., Tallapragada P. 2012. Phosphate solubilizers from the rhizosphere of Piper nigrum L. in Karnataka, India. Chilean Journal of Agricultural Research.72, 397-403.

48. Sharma S.B., Sayyed R.Z., Trivedi M.H., Gobi T.A. 2013. Phosphate solubilizing microbes: sustainable approach for managing phosphorus deficiency in agricultural soils. Springerplus 2, 587-600.

49. Šimanský V., Klimaj A. 2017. How does biochar and biochar with nitrogen fertilization influence soil reaction?. Journal of Ecological Engineering, 18(5), 50-54.

50. Somarathne R., Yapa P., Yapa N. 2013. Use of Different Carrier Materials for Culture and Storage of Native Forest Soil Microorganisms. 3rd International Conference on Ecological, Environmental and Biological Sciences (ICEEBS'2013) April 29-30, 2013, Singapore.

51. Spokas K.A., Cantrell K.B., Novak J.M, Archer D.W., Ippolito J.A., Collins H.P., Boateng A.A.,
Lima I.M., Lamb M.C., McAloon A.J., Lentz R.D., Nichols K.A. 2011. Biochar: a synthesis of its agronomic impact beyond carbon sequestration. Journal of Environmental Quality, 41, 973-989.

52. Stephens J.H.G., Rask H.M. 2000. Inoculant production and formulation. Field Crops Research, 65, 249-258.

53. Subagyo H., Suharta N., Siswanto A.B. 2004. Agricultural Soils in Indonesia. p. 21-66. In Adimihardja A., Amien L.I., Agus F., Djaenudin D. (Eds.). Indonesia's Land Resources and Its Management. Center for Soil and Agroclimate Research and Development, Bogor (in Indonesian).

54. Sukartono, Utomo W.H., Kusuma, Z., Nugroho W.H. 2011. Soil fertility status, nutrient uptake, and maize (Zea mays L.) yield following biochar and cattle manure application on sandy soil of Lombok, Indonesia. Journal of Tropical Agriculture, 49(1-2), 47-52.

55. Sundara B., Natarajan V., Hari K. 2002. Influence of phosphorus solubilizing bacteria on the changes in soil available phosphorus and sugarcane and sugar yields. Field Crops Research, 77, 43-49.

56. Uzoma K.C., Inoue M., Andry H., Fujimaki H., Zahoor A., Nishihara E. 2011. Effect of cow manure biochar on maize productivity under sandy soil condition. Soil Use and Management. Wiley Online Library, USA.

57. Warnock D.D., Lehmann J., Kuyper T.W., Rillig M.C. 2007. Mycorrhizal responses to biochar in soil-concepts and mechanisms. Plant and Soil, 300, 9-20.

58. Widowati, Utomo W.H., Soehono L.A., Guritno B. 2011. Effect of biochar on the release and loss of nitrogen from urea fertilization. Journal of Agriculture and Food Technology, 1(7),127-132

59. Zhao K., Penttinen P., Zhang X., Ao X., Liu M., Yu X., Chen Q. 2014. Maize rhizosphere in Sichuan, China, hosts plant growth promoting Burkholderia cepacia with phosphate solubilizing and antifungal abilities. Microbiological Research, 169,76-82.

60. Zhu H.J., Sun L.F., Zhang Y.F., Zhang X.L., Qiao J.J. 2012. Conversion of spent mushroom substrate to biofertilizer using a stress-tolerant phosphatesolubilizing Pichia farinose FL7. Bioresource Technology, 11, 410-416. 